\title{
Sclerostin Deficiency Alters Peripheral B Lymphocyte Responses in Mice
}

Arthur Chow BS ${ }^{1}$, Jourdan Mason BS ${ }^{1}$, Larrisha Coney BS ${ }^{1}$, Jamila Bajwa BS ${ }^{1}$, Cameron Carlisle BS ${ }^{1}$, Anna Zaslavsky BS ${ }^{1}$, Yvette Pellman $\mathrm{BS}^{1}$, Marcos E. García-Ojeda $\mathrm{PhD}^{1}$, Aris Economides $\mathrm{PhD}^{2}$,

Gabriela G. Loots $\mathrm{PhD}^{1.3}$ and Jennifer O. Manilay $\mathrm{PhD}^{1}$

${ }^{1}$ University of California - Merced, Department of Molecular Cell Biology, School of Natural Sciences, Merced, CA, 95343, USA

${ }^{2}$ Regeneron Pharmaceuticals, 777 Old Saw Mill River Road, Tarrytown, NY 10591, USA

${ }^{3}$ Lawrence Livermore National Laboratories, Physical and Life Sciences Directorate, Livermore, CA 94550, USA.

\section{Corresponding Author:}

Jennifer O. Manilay, PhD

University of California - Merced

School of Natural Sciences

5200 North Lake Road

Merced, CA 95343

Telephone: 209-228-4175

Email: jmanilay@ucmerced.edu 


\begin{abstract}
$\underline{\text { Abstract }}$
Understanding how changes in bone physiology and homeostasis affect immune responses will inform how to retain strong immunity in patients with bone disease and in aged individuals. We previously identified sclerostin (Sost) as a mediator of cell communication between the skeletal and the immune system. Elevated bone mineral density in Sost-knockout $\left(\right.$ Sost $\left.^{-/}\right)$mice contributes to an altered bone marrow microenvironment and adversely affects B cell development. B cells originate from hematopoietic stem cells within the bone marrow and mature in peripheral lymphoid organs to produce antibodies in response to infection and/or vaccination. In this study, we investigated whether the aberrant B cell development observed in the bone marrow of Sost ${ }^{-/}$mice extends to peripheral B cells in the spleen during immune challenge, and if these changes were age-dependent. Concomitant with more severe changes in bone architecture, B cell development in the bone marrow and in the spleen worsened with age in Sost ${ }^{-/}$mice. B cell responses to T-independent antigens were enhanced in young Sost $^{-/-}$mice, whereas responses to T-dependent antigens were impaired. Our results support the hypothesis that the adverse effects of B cell development in the Sost-deficient bone marrow microenvironment extends to the peripheral B cell immune response to protein antigens, and suggest that the B cell response to routine vaccinations should be monitored regularly in patients being treated with sclerostin antibody therapy. In addition, our results open the possibility that Sost regulates the T-independent B cell response, which might be applicable to the improvement of vaccines towards non-protein antigens.
\end{abstract}

Keywords: sclerostin, B lymphocyte, immunity, osteoimmunology, vaccination 


\section{$\underline{\text { Introduction }}$}

Sclerostin-antibody therapy (Scl-Ab, romozosumab) has shown great promise for the treatment of osteoporosis, but the possible side effects of Scl-Ab administration and sclerostin depletion outside of the skeletal system are incompletely understood. Our previous work in the global Sost ${ }^{-/-}$mouse revealed that B lymphocyte development in the bone marrow (BM) was adversely affected, resulting in reduced mature $\mathrm{B}$ cell numbers in the BM with high apoptotic activity ${ }^{(1)}$ and our recent work using conditional Sost ${ }^{-/}$ mice demonstrated a key role for Sost in mesenchymal stem cells on B cell maturation ${ }^{(2)}$. Despite this reduction in the BM, no differences in B lymphocyte number were observed in the spleen. These results suggested that the obstruction in B cell development in Sost ${ }^{-/}$mice was limited to bone marrow B cells, and that any B cells that completely matured then migrated to the spleen to fulfill normal immune functions in the periphery. In our original study, we focused our analyses on mice at peak bone mineral density (12-16 weeks of age), but patients enrolled in Scl-Ab clinical trials span an age range of 55-90 years ${ }^{(3,4)}$. To more closely align our investigations with potential clinical outcomes of Scl-Ab administration in older individuals, we compared the effects of sclerostin deficiency on B cell development and the humoral immune response in young and aged mice. 


\section{$\underline{\text { Materials and Methods }}$}

Mice. Sost ${ }^{-/}$mice have been previously described ${ }^{(1)}$. Mice of both sexes were used on the C57BL/6 background and housed in sterile, microisolator cages with autoclaved feed and water. The UC Merced IACUC approved all animal work.

Flow cytometric analysis of bone marrow and spleen cells. Procedures for euthanasia, dissection and preparation of femurs, tibias and spleens were performed as previously described ${ }^{(1)}$. Details on bone marrow cell harvest and antibody staining are described in Supporting Information.

Immunizations and ELISA. Pre-immune serum was collected from all mice. Mice were injected intraperitoneally with sterile PBS or $\mathrm{NP}_{55}$-Ficoll $(25 \mu \mathrm{g} / 100 \mu 1 \mathrm{PBS})$ or $\mathrm{NP}_{15}$-OVA (50 $\left.\mu \mathrm{g} / 100 \mu 1 \mathrm{PBS}\right)$, (Biosearch Technologies, Inc.). Mice treated with NP-OVA received two injections; the first in the presence of Alhydrogel adjuvant (InvivoGen, Inc.) and the second 14 days later without adjuvant. Serum was collected 8 days after NP-Ficoll injection or 7 days after the second NP-OVA injection, and was used immediately or stored at $-80^{\circ} \mathrm{C}$. ELISA plates (Fisherbrand) were plated with serial dilutions of purified mouse IgM, IgG3 or IgG1 (BioLegend) to create a standard curve. Sample wells were coated with $1 \mu \mathrm{g}$ of NP-BSA (Biosearch Technologies) in $100 \mu \mathrm{l}$ of $0.1 \mathrm{M} \mathrm{Na}_{2} \mathrm{PO}_{4} \mathrm{pH} 9.0$ for $12-18$ hours at $4^{\circ} \mathrm{C}$, rinsed with (PBS-0.05\% Tween 20) twice and the plate blotted to remove excess liquid. Blocking buffer (1.0\% BSA in PBS- $0.05 \%$ Tween 20, 0.05\% sodium azide) was then incubated for 1 hour at room temperature, and wells washed and blotted. Diluted serum samples $(100 \mu \mathrm{l})$ were plated into NP-BSA coated wells, incubated overnight at $4^{\circ} \mathrm{C}$, and wells washed and blotted 3 times. Horseradish peroxidase (HRP)conjugated anti-mouse IgM, IgG3 or IgG1 (Southern Biotech, Inc.) was incubated for 30 minutes at room temperature, and wells washed and blotted 4 times. TMB Substrate Solution (Vector Laboratories, Inc.) was prepared per the manufacturer's instructions, added to each well, and incubated for 20 minutes at room temperature. Fifty microliters of Stop Solution (1N sulfuric acid) was added to each well, and the 
absorbance read at $450 \mathrm{~nm}$ on a plate reader (Perkin Elmer) within 30 minutes. Serum concentrations of NP-specific IgM, IgG3 and IgG1 were calculated using the standard curve.

Statistics. All data were expressed as the mean \pm standard deviation. For flow cytometry results, statistical analysis was done using Student's t-test with a two-tailed distribution, with two-sample equal variance (homoscedastic test). For ELISA, both t-tests and ordinary one-way ANOVA with multiple comparisons tests were performed. For all tests, $\mathrm{p}<0.05$ was considered to be statistically significant. 


\section{$\underline{\text { Results }}$}

Sost $^{-/}$mice display age-related changes in B cell populations in the bone marrow and spleen

Changes in bone architecture are evident as early as 5 weeks of age in Sost $^{-/-}$mice ${ }^{(5)}$. To determine whether Sost ${ }^{-/}$mice exhibit an age-dependent functional defect in B lymphocytes, we compared the B cell frequencies and numbers in the BM and spleens of "young" (1-3 months of age) and "aged" (>11 months of age) Sost $t^{-/}$mice. We found that young Sost $^{-/}$mice displayed similar total B cell $\left(\mathrm{B} 220^{+} \mathrm{IgM}^{+}\right.$and $\left.\mathrm{CD} 19^{+} \mathrm{B} 220^{+}\right)$frequencies and absolute cell counts in the BM to that of age-matched wild-type (WT) controls (Figure 1A-C and Supp. Figure 1). In addition, the frequency of mature B220 high $\operatorname{IgM}^{+} \mathrm{B}$ cells in the young Sost ${ }^{-/} \mathrm{BM}$ was decreased (Figure $1 \mathrm{G}$ ), but this did not result in a difference in cell number (Figure 1H). Aged Sost ${ }^{-/}$mice displayed a more dramatic bone mineral density defect, where the bone marrow cavity was almost completely occluded. As expected, total BM cellularity (Figure 1A) and the frequency of B cells present in the BM were significantly decreased in these mice compared to age-matched controls (Figure 1A, B, G, H). We previously reported that in 12-16 week old Sost ${ }^{-/}$mice, the block in B cell development begins at the pro-B cell stage and is maintained to Fraction D (B220 $\mathrm{CD} 43^{+} \operatorname{IgM}^{-} \operatorname{IgD}^{-;}$late pre-B cell stage $)$, and Fraction $\mathrm{F}\left(\mathrm{B} 220^{+} \mathrm{CD}^{-} 3^{-} \operatorname{IgM}^{+} \operatorname{IgD}^{+}\right)$was also reduced in the bone marrow in frequency and absolute number ${ }^{(1)}$ In the current study, we did not observe any differences between the frequencies of any of the Hardy subsets ${ }^{(6)}$ in young $(<3$ months $)$ control and Sost $^{-/}$mice (Figure 1I), but still observed a clear reduction in the absolute number of Fraction D, and increase in Fraction E, and reduction in Fraction F cell numbers in the Sost ${ }^{-/-}$mice (Table 1). The reduction in the absolute numbers of Fraction D and Fraction F cells was also observed in 8 week old mice treated with sclerostin-depleting antibody for 6 weeks (data not shown). In aged $\mathrm{Sost}^{-/}$mice (>11 months), no difference between the frequencies of early pre-B $\left(\mathrm{B} 220^{+} \mathrm{cKit}^{-} \mathrm{BP} 1^{+} \mathrm{CD} 25^{+}\right)$and pro-B cells $\left(\mathrm{B} 220^{+} \mathrm{cKit}^{+} \mathrm{BP} 1^{-} \mathrm{CD} 25^{-}\right){ }^{(7)}$ was observed, but there was an increase in the frequencies of Fraction D and Fraction E cells, and a reduced frequency of Fraction F cells (Figure 1J). This suggests that there is a progressive block in bone marrow B cell development beginning at the pro-B cells stage that becomes 
more severe with age in Sost ${ }^{-/}$mice, which hinders the maturation of Fraction D and Fraction E cells to the Fraction F stage. Consistent with the reduced bone marrow cellularity observed in Sost $t^{-/}$mice with age, all B cell fractions were significantly reduced in aged Sost ${ }^{-/}$mice (Table 1).

After completing B cell development in the BM, B cells migrate to peripheral lymphoid organs, such as the spleen. Young Sost ${ }^{-/}$and control mice displayed similar splenic B cell frequencies and numbers (Figure 1D-F). In contrast, aged Sost ${ }^{-/}$mice contained a lower percentage of peripheral B lymphocytes in the spleens (Figure 1E-F). This was particularly surprising, as Sost expression has not been reported in the murine spleen ${ }^{(8)}$.

T-cell independent B cell responses are enhanced in young sclerostin-knockout mice

T-independent B cell responses are mediated by marginal zone (MZ) B cells in the spleen ${ }^{(9)}$. We quantified the frequencies and absolute numbers of splenic marginal zone B cells in naive young and aged WT and Sost ${ }^{-/}$mice using flow cytometry ${ }^{(10)}$. No differences in the frequencies of MZ B cells between young and aged mice within the same genotype (e.g. young WT vs. aged WT) or different genotypes (young WT vs. young $S_{0 s}{ }^{-/}$) were observed (Supp. Table 1). However, aged WT and Sost $^{-/}$mice expressed a lower absolute number of marginal zone B cells compared to their younger counterparts (although this was only statistically significant for the WT mice (Supp. Table 1). Therefore, it appears that MZ B cell numbers are reduced with aging, but not necessarily affected by the lack of Sost.

Peripheral B cell responses against T-independent antigens were tested using immunization with NP-Ficoll, a classic multimeric, repeating epitope-bearing T-independent type 2 (T1-2) antigen that simulates an immune response to polysaccharide antigens similar to those found on bacterial cell walls ${ }^{(11,12)}$ (Figure 2A). We quantified the NP-specific T-independent immune response in Sost ${ }^{-/}$mice by ELISA for NP-specific antibodies of the IgM and IgG3 isotypes in the peripheral blood ${ }^{(13)}$ and compared these responses to age matched controls. Antibody titers in immunized mice were compared to pre- 
immunization levels, as well as to $\mathrm{WT}$ and $\mathrm{Sost}^{-/}$mice that received injections of phosphate-buffered saline (PBS). Young immunized WT and Sost $t^{-/}$mice both elicited a strong NP-specific response compared to saline-treated controls (Figure 2B, 2C). No differences in the IgM titers were observed in NP-Ficoll immunized young or aged Sost $^{-/}$mice compared to controls (Figure 2B, 2D). The levels of NPspecific IgG3 were slightly higher in the immunized young Sost $^{-/}$mice compared to age-matched immunized controls (Figure 2C). This IgG3 response in the immunized aged control and Sost $t^{-/}$mice (Figure 2E) was similar, suggesting that aged Sost ${ }^{-/}$mice have normal immunity to T-independent antigens.

T-cell dependent B cell responses are diminished in young sclerostin-knockout mice

T-cell dependent B cell responses are mediated by follicular B cells ${ }^{(9,14)}$. Frequencies and absolute number of follicular B cells were not affected by age or absence of Sost (Supp. Table 1). To determine whether Sost ${ }^{-/}$mice respond to T-dependent antigens, Sost ${ }^{-/}$and control mice were immunized with NP-OVA and B-cell responses were quantified. In this model, NP-OVA stimulates a B cell response to a protein antigen and requires induction of cytokines from $\mathrm{CD}^{+} \mathrm{T}$ helper cells to initiate the appropriate signals for isotype class switching from $\operatorname{IgM}$ to $\operatorname{IgG1}{ }^{(15,16)}$ after a "booster" injection in B lymphocytes (Figure 2F). Young Sost ${ }^{-/}$mice and controls mounted a similar IgM response to NP-OVA (Figure 2G), mirroring the response observed with the NP-Ficoll injections (Figure 2B). However, secondary immunization did not initiate isotype class switching to IgG1 in young Sost ${ }^{-/}$mice (Figure $2 \mathrm{H}$ ), compared to the clear presence of NP-specific IgG1 antibodies in the young WT controls. No significant differences in immune responses were observed between aged Sost ${ }^{-/}$and WT controls (Figure 2I, 2J). These data suggest that Sost-deficiency might affect helper T cell maturation and functional response after stimulation. However, no differences in CD4 and CD8 T cell development in the thymus and spleen were evident in $\mathrm{Sost}^{-/}$mice $^{(1)}$, and the ability of T cells from Sost ${ }^{-/}$mice to proliferate after in vitro stimulation 
with concanavalin A was intact (data not shown), demonstrating that signal transduction downstream of the T cell antigen receptor is functional. However, subtle changes resulting in incomplete B cell activation are evident, as in vitro stimulation of Sost $^{-/} \mathrm{B}$ cells with anti-CD40 resulted in weaker blast formation $^{(17)}$ (Supp. Figure 2). 


\section{$\underline{\text { Discussion }}$}

Recent reports on the clinical trials of Scl-Ab aimed at treatment for bone fragility diseases such as osteoporosis demonstrate promising results ${ }^{(3,4)}$. Scl-Ab may also play a therapeutic role in many sclerostin-mediated diseases other than osteoporosis, such as rheumatoid arthritis ${ }^{(18)}$, hypophosphatasia ${ }^{(19)}$, osteogenesis imperfecta ${ }^{(20)}$ and bone rebuilding in multiple myeloma ${ }^{(21)}$. However, the impacts of Scl-Ab therapy on the immune system have not yet been examined. Our results show that the B cell response to protein antigens is diminished in younger $\mathrm{Sost}^{-/}$mice, and these data may be relevant to human pediatric patients that receive $\mathrm{Scl}-\mathrm{Ab}$ for treatment of osteogenesis imperfecta ${ }^{(22)}$. On the other hand, the B cell response to protein antigens was universally weak in both older WT and Sost ${ }^{-/}$mice, which might explain why relatively few of the adult patients receiving Scl-Ab (which itself is a protein antigen) mount an immune response to the $\mathrm{Scl}-\mathrm{Ab}^{(3,4)}$. That is, inhibition of the T-dependent antigen response by Scl-Ab may promote the efficacy and effectiveness of Scl-Ab therapy itself. We have not observed differences in the frequencies, numbers and activation capacity of $\mathrm{T}$ cells in $\mathrm{Sost}^{-/}$mice, but further investigation is necessary to reveal if subtle differences exist within T cell subsets within the Sost $^{-/-}$microenvironment, such as follicular T helper cells ${ }^{(23)}$, which normally promote co-stimulation of B lymphocytes. Cells of the myeloid lineage can also promote cell responses by conventional B cells ${ }^{(24)}$, providing an alternative area for experimentation.

Our previous studies demonstrated no effect on Sost deficiency on the in vitro B cell response to the T-independent type 1 (TI-1) antigen lipopolysaccharide ${ }^{(1)}$. Thus, the enhanced ability of B cells in younger Sost ${ }^{-/}$mice to respond to NP-Ficoll (a TI-2 antigen) in vivo, is intriguing. Responses to Tindependent antigens can be mediated by innate-like B cells, such as unconventional B-1 lymphocytes (a fetally-derived cell population that persists during adulthood in the peritoneal cavity and mucosa, and may also develop postnatally in the $\left.\mathrm{BM}^{(25,26)}\right)$, and splenic marginal zone B cells ${ }^{(27)}$. Further investigation is required to determine the mechanisms underlying the enhanced $\mathrm{IgG} 3$ response to Tindependent antigens in the younger Sost ${ }^{-/-}$mice, such as a simple decrease in conventional B 
lymphocytes, and if sclerostin deficiency promotes expansion, activation and/or changes in Fc receptor expression in innate-like B cell subsets ${ }^{(28)}$. There is evidence that the function of marginal zone B cells declines with age ${ }^{(29)}$. The IgG3 response to T-independent antigens was somewhat higher in aged WT mice compared to younger WT mice, yet similar between younger and aged Sost ${ }^{-/}$mice. This suggests that there is a role of Sost on innate-like B cells or their microenvironments ${ }^{(30)}$ that may control the intensity of their T1-2 response to a basal (young) level.

The mechanisms that drive the relationship between Sost, Wnt and B cell development are not clearly understood. The role of Wnt signaling in B cell development is somewhat controversial. No differences in Wnt target gene expression was observed in B cells in the bone marrow of Sost $t^{/-}$mice $^{(1)}$, suggesting that Wnt signaling in B cells is not driving the functional differences we have observed in the current study. In line with this, studies of B cell development in beta-catenin knockout mice demonstrated that B cell development is not dependent on canonical Wnt signaling; however, enhanced IgG3 class switching was observed in vitro, but no differences in T-independent or T-dependent B cell responses to antigen were observed in vivo ${ }^{(31)}$. Mice that lack the Fanconi anemia gene Fancc experience progressive bone marrow failure, and $\mathrm{FanCc}^{-/-} \mathrm{B}$ cells display enhanced Wnt signaling, impaired B cell survival and impaired generation of antibody-secreting cells ${ }^{(32)}$. The role of noncanonical Wnt signaling in B cell development has also produced conflicting results. Wnt5a-expressing stromal cells enhance the production and proliferation of B cell progenitors in vitro ${ }^{(33)}$, but studies of Wnt5a haploinsufficiency in vivo showed that Wnt5a inhibits proliferation of B cell progenitors ${ }^{(34)}$ and Wnt5a overexpression seemed to favor myeloid cell development over lymphoid development ${ }^{(35)}$. Further investigation is required to settle these controversies and then to identify the specific roles of Sost in the communication between the skeletal and immune systems.

In conclusion, we demonstrate that sclerostin deficiency affects the peripheral B lymphocyte immune response to foreign antigens in mice, which could be relevant to the ongoing human clinical trials of Scl-Ab therapies. Our data suggest that B cell responses to both T-independent and T-dependent 
bioRxiv preprint doi: https://doi.org/10.1101/357772; this version posted October 16,2018 . The copyright holder for this preprint (which was not certified by peer review) is the author/funder. All rights reserved. No reuse allowed without permission.

antigens, such as those found in routinely administered vaccines, be regularly monitored in patients that receive $\mathrm{Scl}-\mathrm{Ab}$ treatment, as these therapies might inadvertently result in impaired B cell responses. 


\section{Figure Legends}

Figure 1. Comparison of B cell development in $\mathrm{Sost}^{-/-}$mice by age

Total cellularity of BM (A) and spleen (D) in young (1-3 months) and aged (>11 months) WT and Sost ${ }^{-/}$ mice; frequency (\%) of $\mathrm{B} 220^{+} \mathrm{IgM}^{+}$and $\mathrm{CD} 19^{+} \mathrm{B} 220^{+}$cells in $\mathrm{BM}(\mathrm{B}, \mathrm{C})$, and spleen $(\mathrm{E}, \mathrm{F}), \%$ and number of mature (recirculating) $B 220^{\text {high }}, \operatorname{IgM}^{+}(\mathrm{G}, \mathrm{H})$ cells in bone marrow, and $\%$ of cells at distinct stages of maturation in the BM (I, J) of young and older WT and $S_{0 s t^{-/}}$mice, based on flow cytometric analysis. Asterisks indicate statistical significance: ${ }^{*} \mathrm{p}<0.05, * * * \mathrm{p}<0.001, * * * * \mathrm{p}<0.0001$. Each circle represents an individual mouse.

Figure 2. Humoral immune responses after vaccination in young and aged Sost $^{-/-}$mice

A-E) Analysis of T-independent B cell responses: Experimental design (A); Analysis of NP-specific IgM titers and IgG3 titers in young WT and $\operatorname{Sost}^{-/}$mice $(\mathrm{B}, \mathrm{C})$, Analysis of NP-specific IgM titers and IgG3 titers in aged WT and Sost ${ }^{-/}$mice (D, E). F-J) Analysis of T-dependent B cell responses: Experimental design (F); Analysis of NP-specific IgM titers and IgG1 titers in young WT and Sost ${ }^{-/}$mice $(\mathrm{G}, \mathrm{H})$, Analysis of NP-specific IgM titers and IgG1 titers in aged WT and Sost ${ }^{-/}$mice (I, J). Asterisks indicate statistical significance: ${ }^{*} \mathrm{p}<0.05, * * * \mathrm{p}<0.001,{ }^{* * * *} \mathrm{p}<0.0001$. Each symbol represents an individual mouse. 


\begin{tabular}{|c|c|c|c|c|}
\hline $\begin{array}{l}\text { Population } \\
\text { Mean } \pm \text { SD }\end{array}$ & WT young & Sost $^{-/-}$young & WT aged & Sost $^{-/}$aged \\
\hline $\begin{array}{l}\text { Early pre-B } \\
\left(\mathrm{B} 220^{+} \mathrm{cKit}^{-} \mathrm{BP} 1^{+}\right. \\
\left.\mathrm{CD} 25^{+}\right)\end{array}$ & $\begin{array}{c}8.86 \pm 9.62 \times 10^{4} \\
n=6\end{array}$ & $\begin{array}{c}8.66 \pm 9.85 \times 10^{4} \\
n=6\end{array}$ & $\begin{array}{c}3.39 \pm 3.27 \times 10^{4} \\
\mathrm{n}=13\end{array}$ & $\begin{array}{c}6.20 \pm 6.08 \times 10^{3} * * * * \\
n=17\end{array}$ \\
\hline $\begin{array}{l}\text { Pro-B (B220 } \\
\left.\text { cKit }^{+} \text {BP1 } 1^{-} \mathrm{CD} 25^{-}\right)\end{array}$ & $\begin{array}{c}10.2 \pm 5.56 \times 10^{4} \\
n=6\end{array}$ & $\begin{array}{c}10.5 \pm 7.04 \times 10^{4} \\
\mathrm{n}=6\end{array}$ & $\begin{array}{c}15.3 \pm 9.90 \times 10^{4} \\
\mathrm{n}=13\end{array}$ & $\begin{array}{c}\mathbf{5 . 6 1} \pm \mathbf{5 . 1 6} \times 10^{4} * * * \\
\mathrm{n}=17\end{array}$ \\
\hline 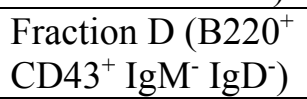 & $\begin{array}{c}9.15 \pm 2.03 \times 10^{5} \\
n=6\end{array}$ & $\begin{array}{c}\mathbf{6 . 0 2} \pm \mathbf{2 . 6 3} \times 10^{5 *} \\
n=6\end{array}$ & $\begin{array}{c}3.82 \pm 2.29 \times 10^{5} \\
\mathrm{n}=18\end{array}$ & $\begin{array}{c}1.21 \pm 7.18 \times 10^{4} * * * \\
n=22\end{array}$ \\
\hline $\begin{array}{l}\text { Fraction E (B220 } \\
\left.\text { CD43 }^{+} \operatorname{IgM}^{+} \text {IgD }^{-}\right)\end{array}$ & $\begin{array}{c}1.96 \pm 8.61 \times 10^{4} \\
n=6\end{array}$ & $\begin{array}{c}7.04 \pm 2.78 \times 10^{4 * * *} \\
n=6\end{array}$ & $\begin{array}{c}1.51 \pm 8.04 \times 10^{4} \\
\mathrm{n}=18\end{array}$ & $\begin{array}{c}4.79 \pm 3.12 \times 10^{4} * * * \\
n=22\end{array}$ \\
\hline $\begin{array}{l}\text { Fraction F }\left(\mathrm{B} 220^{+}\right. \\
\left.\mathrm{CD}^{+} 3^{-} \operatorname{IgM}^{+} \mathrm{IgD}^{+}\right)\end{array}$ & $\begin{array}{c}3.81 \pm 1.65 \times 10^{6} \\
\mathrm{n}=6\end{array}$ & $\begin{array}{c}\mathbf{1 . 6 6} \pm \mathbf{0 . 6 6} \times 10^{5 *} \\
\mathrm{n}=6\end{array}$ & $\begin{array}{c}5.05 \pm 2.77 \times 10^{6} \\
\mathrm{n}=18\end{array}$ & $\begin{array}{c}4.36 \pm 4.23 \times 10^{5} * * * \\
n=22\end{array}$ \\
\hline
\end{tabular}




\section{$\underline{\text { Acknowledgments }}$}

This work was supported by University of California, Merced faculty research funding to J.O.M. and a student research grant to A.C. GGL works under the auspices of the U.S. Department of Energy by Lawrence Livermore National Laboratory under Contract DE-AC52-07NA27344. Authors' roles: AE and GL provided the Sost ${ }^{-/}$mice to begin our colony at UC Merced. Study design: JOM. Study conduct: JOM. Data collection: AC, JM, LC, JB, CC, AZ, YP, MGO. Data analysis: AC, JM, LC, JB, CC, AZ, YP and JOM. Data interpretation: JOM and GL. Drafting manuscript: JOM. Revising manuscript content: GL, MGO and JOM. Approving final version of manuscript: JOM. JOM takes responsibility for the integrity of the data analysis. The authors thank the staff of the Department of Animal Research Services and the Flow Cytometry Core of the Stem Cell Instrumentation Foundry at UC Merced for excellent animal care and technical support. 


\section{Literature Cited}

1. Cain CJ, Rueda R, McLelland B, Collette NM, Loots GG, Manilay JO. Absence of sclerostin adversely affects B-cell survival. J Bone Miner Res. Jul 2012;27(7):1451-61.

2. Yee CS, Manilay JO, Chang JC, Hum NR, Murugesh DK, Bajwa J, et al. Conditional Deletion of Sost in MSC-derived lineages Identifies Specific Cell Type Contributions to Bone Mass and B Cell Development. J Bone Miner Res. May 11 2018. Epub 2018/05/12.

3. McClung MR, Brown JP, Diez-Perez A, Resch H, Caminis J, Meisner P, et al. Effects of 24 months of treatment with romosozumab followed by 12 months of denosumab or placebo in postmenopausal women with low bone mineral density: A randomized, double-blind, phase 2, parallel group study. J Bone Miner Res. Apr 25 2018. Epub 2018/04/26.

4. $\quad$ Langdahl BL, Libanati C, Crittenden DB, Bolognese MA, Brown JP, Daizadeh NS, et al. Romosozumab (sclerostin monoclonal antibody) versus teriparatide in postmenopausal women with osteoporosis transitioning from oral bisphosphonate therapy: a randomised, open-label, phase 3 trial. Lancet. Sep 30 2017;390(10102):1585-94. Epub 2017/08/02.

5. Li X, Ominsky MS, Niu QT, Sun N, Daugherty B, D'Agostin D, et al. Targeted deletion of the sclerostin gene in mice results in increased bone formation and bone strength. J Bone Miner Res. Jun 2008;23(6):860-9.

6. Hardy RR, Carmack CE, Shinton SA, Kemp JD, Hayakawa K. Resolution and characterization of pro-B and pre-pro-B cell stages in normal mouse bone marrow. J Exp Med. May 1991;173(5):1213-25.

7. Khass M, Buckley K, Kapoor P, Schelonka RL, Watkins LS, Zhuang Y, et al. Recirculating bone marrow B cells in C57BL/6 mice are more tolerant of highly hydrophobic and highly charged CDR-H3s than those in BALB/c mice. Eur J Immunol. Mar 2013;43(3):629-40. Epub 2012/12/12.

8. Collette NM, Yee CS, Murugesh D, Sebastian A, Taher L, Gale NW, et al. Sost and its paralog Sostdc1 coordinate digit number in a Gli3-dependent manner. Dev Biol. Nov 2013;383(1):90105.

9. Swanson CL, Pelanda R, Torres RM. Division of labor during primary humoral immunity. Immunol Res. Mar 2013;55(1-3):277-86. Epub 2012/09/05.

10. Allman D, Pillai S. Peripheral B cell subsets. Curr Opin Immunol. Apr 2008;20(2):149-57.

11. Obukhanych TV, Nussenzweig MC. T-independent type II immune responses generate memory B cells. J Exp Med. Feb 20 2006;203(2):305-10. Epub 2006/02/16.

12. Vinuesa CG, Sze DM, Cook MC, Toellner KM, Klaus GG, Ball J, et al. Recirculating and germinal center B cells differentiate into cells responsive to polysaccharide antigens. Eur J Immunol. Feb 2003;33(2):297-305. Epub 2003/01/28.

13. Maizels N, Lau JC, Blier PR, Bothwell A. The T-cell independent antigen, NP-ficoll, primes for a high affinity IgM anti-NP response. Mol Immunol. Dec 1988;25(12):1277-82.

14. Gatto D, Brink R. The germinal center reaction. J Allergy Clin Immunol. Nov 2010;126(5):898907; quiz 8-9.

15. Victora GD, Schwickert TA, Fooksman DR, Kamphorst AO, Meyer-Hermann M, Dustin ML, et al. Germinal center dynamics revealed by multiphoton microscopy with a photoactivatable fluorescent reporter. Cell. Nov 2010;143(4):592-605.

16. Jin BR, Kim SJ, Lee JM, Kang SH, Han HJ, Jang YS, et al. Alum Directly Modulates Murine B Lymphocytes to Produce IgG1 Isotype. Immune Netw. Feb 2013;13(1):10-5. Epub 2013/04/06.

17. van Essen D, Kikutani H, Gray D. CD40 ligand-transduced co-stimulation of T cells in the development of helper function. Nature. Dec 7 1995;378(6557):620-3. Epub 1995/12/07.

18. Wehmeyer C, Frank S, Beckmann D, Bottcher M, Cromme C, Konig U, et al. Sclerostin inhibition promotes TNF-dependent inflammatory joint destruction. Sci Transl Med. Mar 16 2016;8(330):330ra35. Epub 2016/04/19. 
19. Seefried L, Baumann J, Hemsley S, Hofmann C, Kunstmann E, Kiese B, et al. Efficacy of antisclerostin monoclonal antibody BPS804 in adult patients with hypophosphatasia. J Clin Invest. Apr 242017.

20. Glorieux FH, Devogelaer JP, Durigova M, Goemaere S, Hemsley S, Jakob F, et al. BPS804 AntiSclerostin Antibody in Adults With Moderate Osteogenesis Imperfecta: Results of a Randomized Phase 2a Trial. J Bone Miner Res. Mar 292017.

21. McDonald MM, Reagan MR, Youlten SE, Mohanty ST, Seckinger A, Terry RL, et al. Inhibiting the osteocyte-specific protein sclerostin increases bone mass and fracture resistance in multiple myeloma. Blood. Jun 29 2017;129(26):3452-64. Epub 2017/05/19.

22. Sinder BP, Lloyd WR, Salemi JD, Marini JC, Caird MS, Morris MD, et al. Effect of antisclerostin therapy and osteogenesis imperfecta on tissue-level properties in growing and adult mice while controlling for tissue age. Bone. Mar 2016;84:222-9. Epub 2016/01/16.

23. Vinuesa CG, Linterman MA, Yu D, MacLennan IC. Follicular Helper T Cells. Annu Rev Immunol. May 20 2016;34:335-68. Epub 2016/02/26.

24. Cerutti A, Qiao X, He B. Plasmacytoid dendritic cells and the regulation of immunoglobulin heavy chain class switching. Immunol Cell Biol. Oct 2005;83(5):554-62. Epub 2005/09/22.

25. Baumgarth N. A Hard(y) Look at B-1 Cell Development and Function. J Immunol. Nov 15 2017;199(10):3387-94. Epub 2017/11/08.

26. Baumgarth N. B-1 Cell Heterogeneity and the Regulation of Natural and Antigen-Induced IgM Production. Front Immunol. 2016;7:324. Epub 2016/09/27.

27. Cerutti A, Cols M, Puga I. Marginal zone B cells: virtues of innate-like antibody-producing lymphocytes. Nat Rev Immunol. Feb 2013;13(2):118-32. Epub 2013/01/26.

28. Shibuya A, Honda SI, Shibuya K. A pro-inflammatory role of Fcalpha/muR on marginal zone B cells in sepsis. Int Immunol. Dec 30 2017;29(11):519-24. Epub 2017/12/28.

29. Turner VM, Mabbott NA. Ageing adversely affects the migration and function of marginal zone B cells. Immunology. Jul 2017;151(3):349-62. Epub 2017/04/04.

30. Birjandi SZ, Ippolito JA, Ramadorai AK, Witte PL. Alterations in marginal zone macrophages and marginal zone B cells in old mice. J Immunol. Mar 15 2011;186(6):3441-51. Epub 2011/02/11.

31. Yu Q, Quinn WJ, 3rd, Salay T, Crowley JE, Cancro MP, Sen JM. Role of beta-catenin in B cell development and function. J Immunol. Sep 15 2008;181(6):3777-83. Epub 2008/09/05.

32. Sertorio M, Amarachintha S, Wilson A, Pang Q. Loss of Fancc Impairs Antibody-Secreting Cell Differentiation in Mice through Deregulating the Wnt Signaling Pathway. J Immunol. Apr 1 2016;196(7):2986-94. Epub 2016/02/21.

33. Sato M, Tamura M. Noncanonical Wnt signaling in stromal cells regulates B-lymphogenesis through interleukin-7 expression. Biochem Biophys Rep. Jul 2016;6:179-84. Epub 2016/04/01.

34. Liang H, Chen Q, Coles AH, Anderson SJ, Pihan G, Bradley A, et al. Wnt5a inhibits B cell proliferation and functions as a tumor suppressor in hematopoietic tissue. Cancer Cell. Nov 2003;4(5):349-60. Epub 2003/12/12.

35. Famili F, Naber BA, Vloemans S, de Haas EF, Tiemessen MM, Staal FJ. Discrete roles of canonical and non-canonical Wnt signaling in hematopoiesis and lymphopoiesis. Cell Death Dis. Nov 19 2015;6:e1981. Epub 2015/11/20. 


\section{Chow et al. Figure 1}
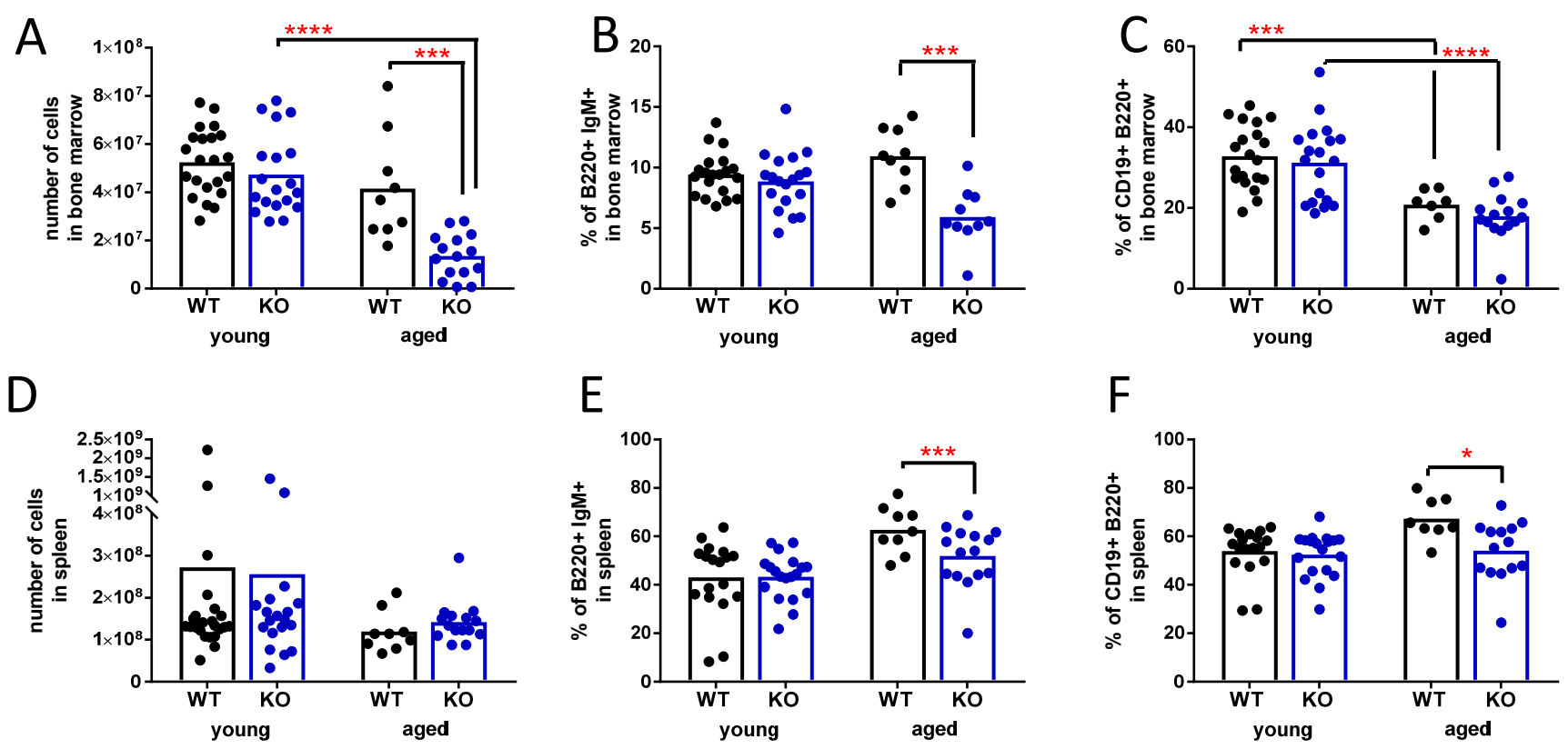

G

$\mathrm{H}$
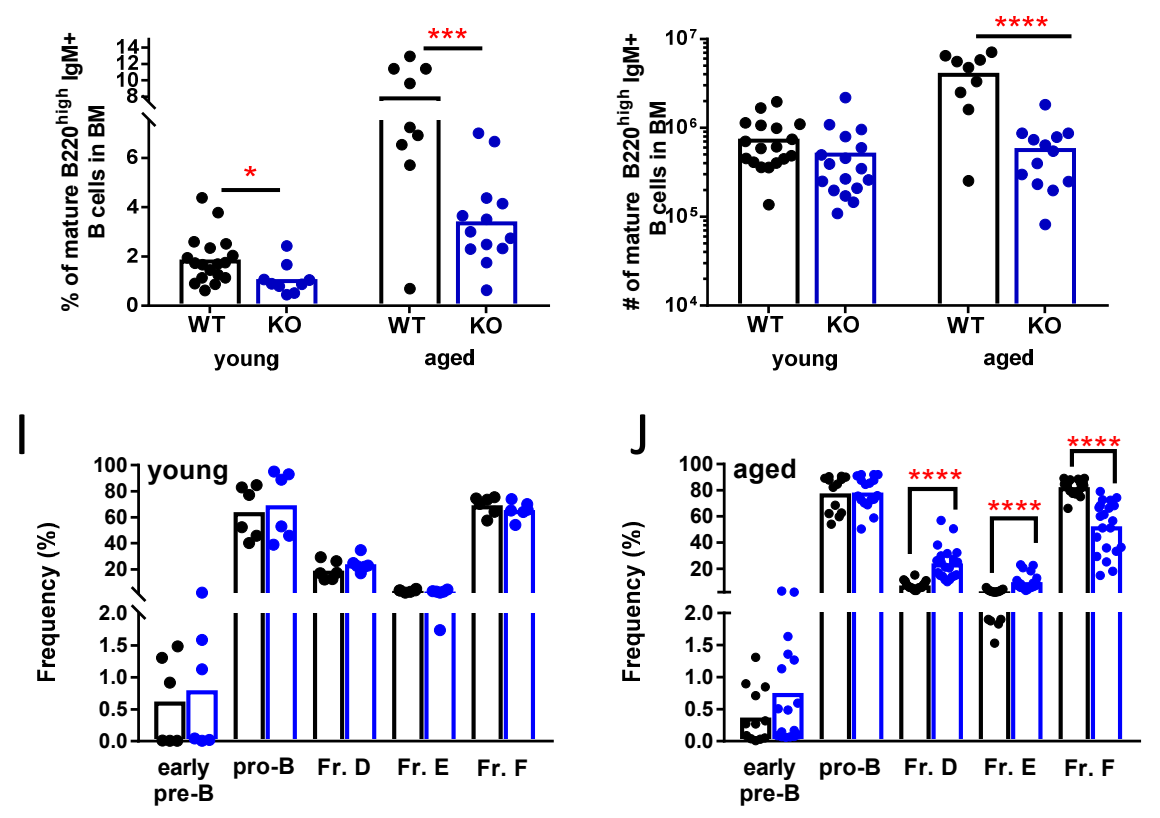


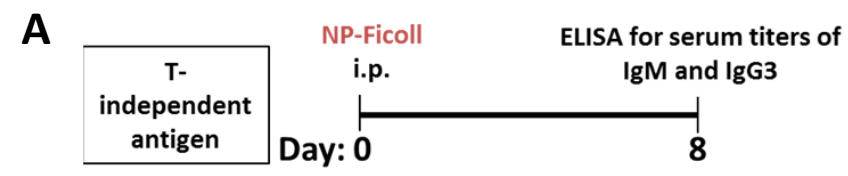

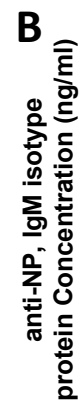

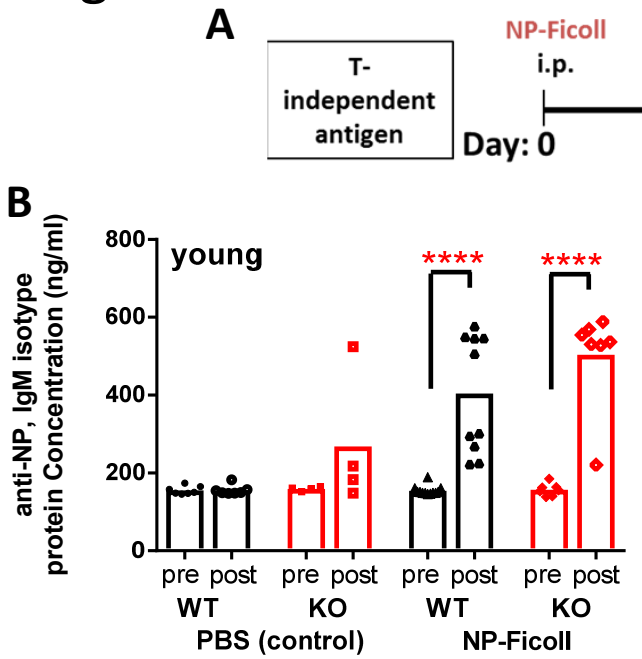

D

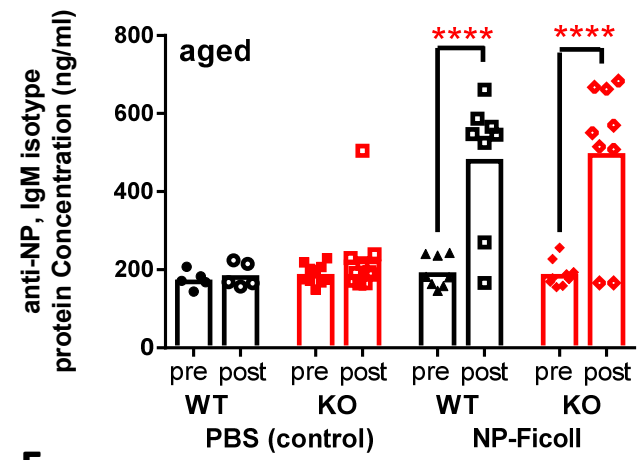

F

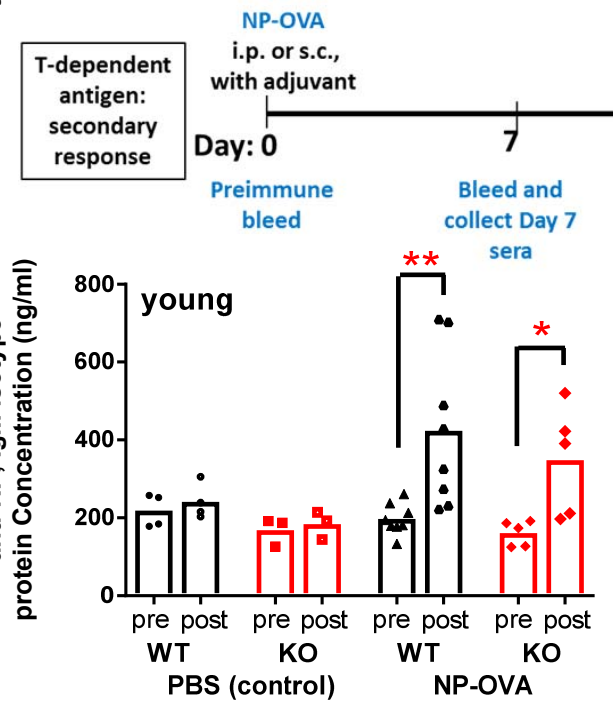

C

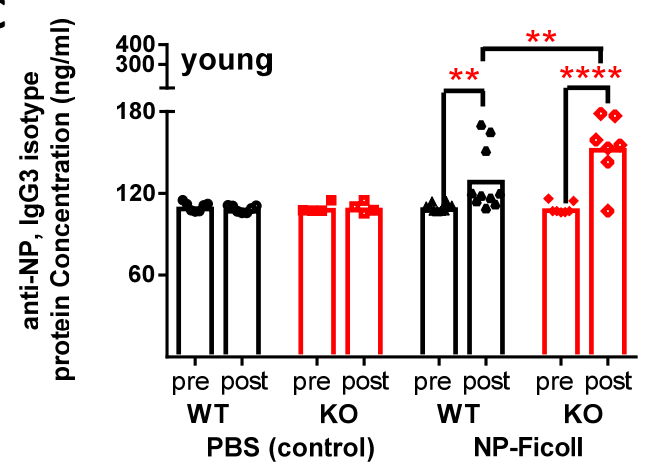

E

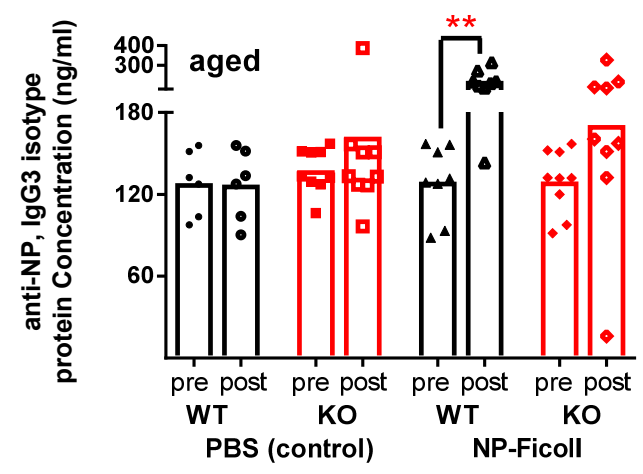

PBS (control) NP-Ficoll

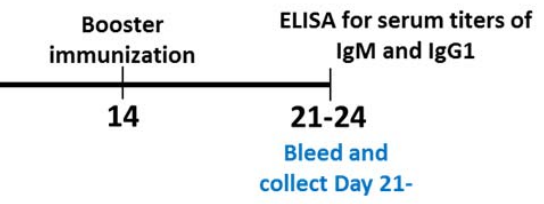

H
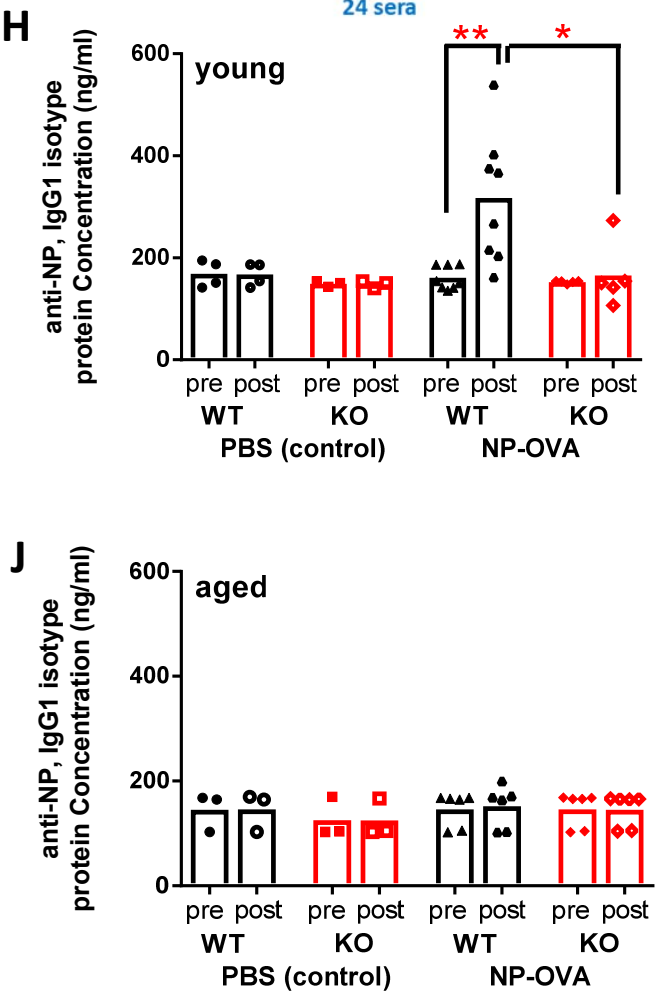